\title{
Mites of the Family Macrochelidae (Acari: Gamasida) from Sungai Wain, East Kalimantan, Indonesia
}

\author{
Dhian Dwibadra ${ }^{1,5}$, Gen Takaku ${ }^{2}$, Masahiro Ôhara ${ }^{3}$ and Akira Ueda ${ }^{4}$ \\ ${ }^{1}$ Systematic Entomology Laboratory, Graduate School of Agriculture, Hokkaido University, \\ Sapporo 060-8589, Japan \\ E-mail: dwibadra_yk@yahoo.com \\ ${ }^{2}$ Biological Laboratory, Hokkaido University of Education Sapporo, \\ 5-3-1 Ainosato, Kita-ku, Sapporo 002-8502, Japan \\ ${ }^{3}$ The Hokkaido University Museum, N 10 W 8, Kita-ku, Sapporo 060-0810, Japan \\ ${ }^{4}$ Kyushu Research Center, Forestry and Forest Products Research Institute (FFPRI), \\ 4-11-16 Kurokami, Kumamoto 860-0862, Japan \\ ${ }^{5}$ Corresponding author
}

(Received 20 June 2013; Accepted 9 May 2014)

\begin{abstract}
Twenty-two mite species of four genera belonging to the family Macrochelidae were collected from the body surface of dung beetles (Scarabaeidae) in Sungai Wain, East Kalimantan, Indonesia. Three species, Macrocheles dayaci sp. nov., M. riparius sp. nov., and $M$. wainensis sp. nov., are described as new to science. Another eight species are recorded from Kalimantan for the first time.
\end{abstract}

Key Words: Acari, Macrochelidae, dung beetles, Sungai Wain, East Kalimantan, Indonesia.

\section{Introduction}

Kalimantan, the Indonesian part of the island of Borneo in Southeast Asia, comprises the largest land area in the Major Sunda Islands in Indonesia. Several taxonomic studies on macrochelid mites have been carried out in Sumatra and Java in the Major Sunda Islands (e.g., Vitzthum 1925; Takaku 2001; Hartini and Takaku 2003a, b; Hartini et al. 2009), where more than 30 species have been recorded, but there has been no comprehensive study of macrochelids in Kalimantan. To date, 16 species of macrochelids have been recorded from Kalimantan by Hartini and Takaku (2003c, 2004) and Hartini et al. (2003), all collected from scarabaeine dung beetles. These species belong to three genera: Macrocheles (10 species), Neopodocinum (5 species), and Holostaspella (1 species). Although most of the species were collected from East Kalimantan, Macrocheles hallidayi Walter and Krantz, 1986, M. kraepelini (Berlese, 1905), and M. sp. aff. glaber (Müller, 1860) were also collected from Central Kalimantan. Of the 16 species which have been described, only one, Neopodocinum kalimantanense Hartini and Takaku, 2003, appear to be endemic to Kalimantan.

Sungai Wain and the forest surrounding it play an important role for people and local industry in Balikpapan, East Kalimantan. The Sungai Wain forest is the water catchment area for Balikpapan city (Frederiksson and De Kam, 1999) and a habitat for the endangered orangutan, Pongo pygmaeus (Linnaeus, 1760).

As a result of our investigation of macrochelid mites in Sungai Wain in 2006-2008, we found 1,564 mite specimens of 22 species belonging to four genera. Three of these spe- cies are described here as new to science and eight species are new records from Kalimantan.

\section{Materials and Methods}

Phoretic beetle hosts examined in the present study were collected in traps baited with fresh human dung or fish fillet set in several kinds of habitat (e.g., Acacia plantation, grassland) in Sungai Wain by A. Ueda and D. Dwibadra. All scarab beetle specimens were fixed in $70 \%$ ethyl alcohol in the field. Collected specimens from one trap were kept in the same vial. Some mites were collected from the ventral surface of the scarab beetles and others, detached from beetles, were collected from residue in the vials in which the scarabs had been fixed and preserved. All mite specimens were preserved in $70 \%$ ethyl alcohol. Some were dissected under a stereoscopic microscope after clearing in lactic acid. Each body part was mounted on a slide in PVA (polyvinyl alcohol-lactic acid mixture) medium. Observations were made with phase contrast and differential interference contrast microscopes. Illustrations were prepared with the aid of a drawing tube.

All measurements are given in micrometres $(\mu \mathrm{m})$. Dorsal chaetotaxy follows Halliday (1987) and other terminology follows Walter and Krantz (1986b).

The holotype specimen of each new species will be deposited in the collection of the Museum Zoologicum Bogoriense, Cibinong, Bogor, Indonesia (MZB), and the remaining specimens will be divided between the MZB and The Hokkaido University Museum, Sapporo, Japan.

Surveys were conducted at several sites around the Wain 
River at Balikpapan, East Kalimantan, Indonesia. Abbreviations of the localities used in the descriptions are as follows:

- BBG: Balikpapan Botanical Garden.

- Km 12 to Km 38: points 12-38 km away from Balikpapan on the road from Balikpapan to Samarinda.

- SWPF: Sungai Wain Protection Forest (= Hutan Lindung Sungai Wain)

Abbreviations for sternal ornamentation used in the descriptions follow Walter and Krantz (1986b) as below:

- a.pf.: area punctiformes

- a. p. 1.: area punctata laterales

- a. p. p.: area punctata posteriores

- 1. ang.: linea angulata

- 1. arc.: linea arcuata

- 1. m. t.: linea media transversa

- 1. o. a.: linea oblique anteriores

- 1. o. p.: linea oblique posteriores

Genus Glyptholaspis Filipponi and Pegazzano, 1960 Glyptholaspis asperrima (Berlese, 1905)

Holostaspis asperrimus Berlese, 1905: 163, fig. 25.

Macrocheles (Macrocheles) asperrimus: Berlese 1918: 172.

Glyptholaspis asperrima: Filipponi and Pegazzano 1960: 166, fig. 9, tav. XI; 1962: 202; Krantz 1967: 150-152; Roy 1989b: 346-348, figs 10-14.

Material examined. Km 18: 1 female, Acacia mangium Willd plantation, 23 December 2006, ex residue in vial. Km 22: 1 female, A. mangium plantation, 23 December 2006, ex Onthophagus semicupreus Harold, 1877. Km 23: 3 females, 17-22 December 2007, ex residue in vial. Km 24: 1 female, A. mangium plantation, 21 December 2006, ex residue in vial; 2 females, 7-12 December 2008, ex residue in vial.

Diagnosis. Female. Dorsal setae $\mathrm{z} 1$ half as long as $\mathrm{j} 1$; setae $\mathrm{j} 6$ and z6 located at same level; J5 as long as Z5; posterior margin of dorsal shield with regularly spaced small teeth between setae Z5. Sternal shield fused with metasternal shield and ornamented with distinct polygonal ornamentation.

Habitat. This species has been collected from the scarab beetle genera Aphodius, Catharsius, Copris, Onitis, and Onthophagus; otherwise it has been collected from cow dung, compost, manure, etc.

Distribution. Indonesia [Bali, Sulawesi, Flores, Java, Kalimantan (new record)], Philippines, China, India, England, Iceland, Italy, Greece, South Africa, Congo, and North America.

\section{Glyptholaspis confusa (Foà, 1900)}

Holostaspis confusus Foà, 1900: 137, figs 5, 5 bis, 6 .

Macrocheles (Macrocheles) vagabundus var. neotropicus Berlese, 1918: 173 [partim].

Macrocheles plumiventris Evans and Browning, 1956: 36; Filipponi and Seganti 1957: 27; Balogh 1958: 253, figs 26-30.

Macrocheles (Macrocheles) confusus: Filipponi and Ilardi
1958: 118.

Glyptholaspis confusa: Filipponi and Pegazzano 1960: 154, figs 5, 6, tav. VII, VIII; Krantz 1972: 270; Halliday 1986: 73; Hyatt and Emberson 1988: 116; Mašán 2003: 122, figs $124-125$.

Material examined. Km 22: 1 female, Acacia mangium plantation, 23 December 2006, ex residue in vial. BBG: 3 females, 4-9 December 2008, ex residue in vial.

Diagnosis. Female. Dorsal shield large, oval, with punctate-reticulate pattern; posterior margin of dorsal shield between setae Z5 with 5 large denticles and numerous microdenticles; most dorsal setae brush-shaped and densely plumose; setae j5 brush-shaped and longer than z6; setae $\mathrm{j} 6, \mathrm{z} 5$, and 1 unpaired median seta between $\mathrm{j} 6$ and $\mathrm{J} 2$ pilose; setae $\mathrm{z} 6$ and $\mathrm{J} 2$ pilose distally; network meshes of sternal and ventrianal shield mostly micropunctured; ventrianal shield with truncate anterior margin; preanal setae short and brush-like.

Habitat. This species has been found from the scarab beetle genera Aphodius, Euoniticellus, Liatongus, and Onthophagus. This was also collected from cadavers and in compost heaps, decaying fodder, silage, and bird nests.

Distribution. Indonesia (Kalimantan; new record), Philippines, Japan, Israel, Turkmenistan, Uzbekistan, Australia, New Zealand, British Isles, Germany, Switzerland, Austria, Slovakia, Italy, Bulgaria, Greece, Russia, Caucasus, and Argentina.

Genus Holostaspella Berlese, 1903

Holostaspella moderata Berlese, 1920

Holostaspella moderata Berlese, 1920: 188.

Holostaspella moderata: Krantz 1967: 130, figs 52, 54.; Filipponi and Pegazzano 1967: figs III, IV, tav. XIX, 3-4, tav. XX, 2; Roy 1989a: 334-335, figs 11-18.

Holostaspella (Holostaspella) egregia Vitzthum, 1925: 16.

Material examined. $\quad \mathbf{K m}$ 24: 1 female, 7-12 December 2008, ex residue in vial.

Diagnosis. Female. Dorsal shield punctate, j1 plumose, on anterior projection of shield; $\mathrm{z} 1$ longer than $\mathrm{j} 1$; dorsal setae weakly or strongly pectinate; sternal shield typical for sculpta species group; st1 plumose, st2-3 short and smooth; ventrianal shield broader than long with 3 pairs of long preanal setae; Jv2 and Zv2 distinctly pectinate, Jv3 distally pectinate; paranal and postanal setae short and smooth.

Habitat. This species has been collected from banana plantation litter, grassy soil, leaf litter, and a refuse dump.

Distribution. Indonesia [Sumatra, Java, Kalimantan (new record)], Philippines, Japan, India, and Australia.

Genus Macrocheles Latreille, 1829

Macrocheles baramensis Evans and Hyatt, 1963

Macrocheles baramensis Evans and Hyatt, 1963: 335-337, figs 15-17.

Macrocheles baramensis: Hartini et al. 2003: 307-308. 
Material examined. SWPF: 3 females, 20 December 2006, ex Paragymnopleurus maurus Sharp, 1875; 6 females, 15-20 December 2007, ex P. maurus; 1 female, 11 December 2008, ex residue in vial. Km 15: 2 females, 19 December 2007, ex Scarabaeinae; 2 females, 11 December 2008, ex P. maurus. Km 24: 2 females, burned ridge, 14-19 December 2007, ex residue in vials; 3 females, 14-19 December 2008, ex $P$. maurus; 1 female, burned valleys, 5-10 December 2008, ex residue in vial. Km 12: 5 females, 15-20 December 2007, ex Scarabaeinae.

Diagnosis. Female. Dorsal shield granular, covered with fine reticulations and bearing 28 pairs of setae; $j 1$ pilose in their distal halves, dorsal setae bipectinate in their distal halves, except simple j5, j6, z5, z6, and J2 (in some cases these slightly pilose). Sternal shield granular with faint linear ornamentation.

Habitat. This species has been collected from the scarab beetle genera Catharsius, Onthophagus, and Paragymnopleurus.

Distribution. Indonesia (Kalimantan) and Malaysia (Sarawak).

\section{Macrocheles dispar (Berlese, 1910)}

Holostaspis dispar Berlese, 1910: 251.

Macrocheles (Coprholaspis) dispar: Berlese 1918: 151.

Macrocheles dispar: Walter and Krantz 1992: 244, fig. 1D; Hartini and Takaku 2003a: 1262-1263, figs 1-6; Hartini et al. 2003: 308 .

Material examined. SWPF: 2 females, 14 December 2007, ex Onthophagus vulpes Harold, 1877 and O. cervicapra Boucomont, 1914; 1 female, 11 December 2008, ex residue in vial. Km 12: 1 female, 15-20 December 2007, ex O. schwaneri Vollenhoven, 1864. Km 24: 1 female, 14-19 December 2007, ex Paragymnopleurus maurus. Km 29: 2 females, 22 December 2006, ex O. schwaneri. Km 38: 5 females, 16-21 December 2007, ex Onthophagus sp., residue in vial.

Diagnosis. Female. Dorsal setae j1 plumose distally; $\mathrm{j} 4, \mathrm{z} 2, \mathrm{z} 4, \mathrm{r} 2-4, \mathrm{~J} 5, \mathrm{Z} 5$, and S5 pilose distally; j2, j3, and s2 simple but in some cases pilose distally; other setae simple. Sternal shield ornamented with lines and punctation; l. ang., l. m. t., l. o. p. with distinct punctations; l. m. t. complete; l. o. p. disjunct from 1. m. t. and not bifurcate; center of posterior half of shield with small punctations.

Habitat. This species has been collected from the scarab beetle genera Aphodius, Catharsius, Copris, Enoplotrupes, Onthophagus, and Paragymnopleurus.

Distribution. Indonesia (Java, Sumatra, Kalimantan, Lombok, and Sulawesi), Viet Nam, Philippines, China (Szechuan), and Taiwan.

\section{Macrocheles entetiensis Hartini and Takaku, 2005}

Macrocheles entetiensis Hartini and Takaku, 2005 in Hartini et al. 2005: 204-206, figs 1-5.
Material examined. Km 18: 5 females, 23 December 2006, ex Onthophagus schwaneri, residue in vial. Km 22: 8 females, 23 December 2006, ex residue in vials. Km 23: 4 females, 23 December 2006, ex O. limbatus Herbs, 1789; 8 females, Imperata cylindrical (L.) grassland, 17-22 December 2007, ex O. uedai Ochi and Kon, 2006 and residue in vials. Km 24: 33 females, 23 December 2006, ex O. limbatus and residue in vials.

Diagnosis. Female. Dorsal setae $\mathrm{j} 1$ pilose distally; $\mathrm{j} 3$ and $\mathrm{z} 4$ thickened and pilose distally; j5, j6, z5, z6, and J2 simple; other dorsal setae pilose distally or pilose in distal half. Sternal shield with distinct l. ang., l. arc., l. m. t., and 1. o. p.; l. o. p. disjunct from 1. m. t. and not bifurcate.

Habitat. This species has been collected from the scarab beetle genera Aphodius, Catharsius, and Onthophagus.

Distribution. Indonesia [Timor, Sumba, Flores, Sumbawa, Java, and Kalimantan (new record)].

\section{Macrocheles hallidayi Walter and Krantz, 1986}

Macrocheles hallidayi Walter and Krantz, 1986a: 214-216, figs $12,13$.

Macrocheles hallidayi: Walter and Krantz 1986b: 289, fig. 1b; Takaku 1998: 30-36, figs 1-14; Takaku 2001: 501, figs 3, 9; Takaku and Hartini 2001: 325; Hartini and Takaku 2003a: 1264; Hartini et al. 2003: 308; Hartini et al. 2005: 202.

Material examined. SWPF: 1 female, 16 December 2006, ex residue in vial; 1 female, 20 December 2006, ex residue in vial; 2 females, 15 December 2007, ex Onthophagus schwaneri and Catharsius dayacus Lansberge, 1886; 1 female, 17 December 2007, ex residue in vial; 1 female, 5 December 2008, ex residue in vial. Km 12: 1 female, 15-20 December 2007, ex O. schwaneri; Km 18: 39 females, 23 December 2006, ex O. schwaneri, O. liliputanus Lansberge, 1883, Onthophagus sp., and residue in vials. $\mathbf{K m ~ 2 2 :}$ 2 females, 23 December 2006, ex residue in vials. Km 23: 5 females, Imperata cylindrica grassland, 17-22 December 2007, ex residue in vial; 8 females, Acacia mangium plantation, 17-22 December 2007, ex Catharsius renaudpauliani Ochi and Kon, 1996 and O. obscurior Boucomont, 1914. Km 24: 29 females, 21 December 2006, ex C. dayacus, residue in vials; 7 females, 26 December 2006, ex O. limbatus, residue in vials; 2 females, burned ridge, 14-19 December 2007, ex O. schwaneri and Paragymnopleurus maurus; 4 females, burned ridge, 6-11 December 2008, ex residue in vial; 16 females, A. mangium plantation, 7-12 December 2008, ex residue in vials; 4 females, I. cylindrica grassland, 7-12 December 2008, ex residue in vials. $\mathbf{K m ~ 2 9 :} 24$ females, 22 December 2006, ex O. cervicapra, O. schwaneri, C. renaudpauliani, and residue in vials. Km 38: 1 female, secondary forest, 16-21 December 2007, ex Onthophagus sp.

Diagnosis. Female. Dorsal shield ornamented with punctate-reticulate pattern and with well developed procurved line; dorsal setae $\mathrm{j} 1$ pilose; $\mathrm{z} 1$ shorter than $\mathrm{j} 1$ and not reaching insertions of $\mathrm{j} 2 ; \mathrm{j} 5, \mathrm{j} 6, \mathrm{z} 5, \mathrm{z6}$, and $\mathrm{J} 2$ simple; J5 serrate; other dorsal setae sparsely to strongly bipectinate. Sternal shield with strongly punctate margin along 1 . ang. and 
with two deeply punctate 1 . arc., well developed l. m. t., l. o. p., and l. ang.; l. o. p. bifurcate, with distinct a. p. p. and a. pf. Genu IV with 7 pectinate setae.

Habitat. This species has been collected from the scarab beetle genera Aphodius, Catharsius, Copris, Heliocopris, Microcopris, Oniticellus, Onitis, Onthophagus, and Paragymnopleurus.

Distribution. Indonesia (Java, Madura, Sumatra, Kalimantan, Bali, Sulawesi, Lombok, Sumbawa, Flores, and Sumba), Malaysia (Sarawak), Thailand, Cambodia, Philippines, and India.

Macrocheles jabarensis Hartini and Takaku, 2003

Macrocheles jabarensis Hartini and Takaku, 2003a: 1266, figs 7-12.

Macrocheles jabarensis: Hartini et al. 2003: 308.

Material examined. SWPF: 32 females, 16 December 2006, ex Onthophagus semicupreus, O. vulpes, O. obscurior, O. cervicapra, O. borneensis Harold, 1877, O. pasificus Lansberge, 1885, Catharsius dayacus, and residue in vials; 14 females, 17 December 2006, ex O. waterstradti Boucomont, 1914, O. schwaneri, O. borneensis, and Onthophagus sp.; 14 females, 18 December 2006, ex O. schwaneri; 30 females, 20 December 2006, ex O. obscurior, O. pastillatus Boucomont, 1919, O. cervicapra, C. dayacus, and residue in vials; 53 females, 14 December 2007, ex C. dayacus, O. schwaneri, O. waterstradti, O. incisus Harold, 1877, O. vulpes, Paragymnopleurus maurus, and residue in vials; 3 females, 12 December 2008, ex O. borneensis; 4 females, 5 December 2008, ex residue in vials; 6 females, 11 December 2008, ex residue in vials. Km 18: 6 females, Acacia mangium plantation, 23 December 2006, ex residue in vials. Km 22: 6 females, A. mangium plantation, 23 December 2006, ex C. renaudpauliani and residue in vials. $\mathbf{K m ~ 2 4 : ~} 1$ female, Imperata cylindrica grassland, 21 December 2006, ex O. papulatus Boucomont, 1914; 5 females, burned secondary forest, 21 December 2006, ex residue in vials; 19 females, secondary forest, 21 December 2006, ex O. aurifex Harold, 1877, O. schwaneri, O. dux Sharp, 1875, C. dayacus, and residue in vials; 16 females, natural forest, 21 December 2006, ex O. schwaneri and residue in vials; 2 females, burned secondary forest, 26 December 2006, ex residue in vial; 4 females, I. cylindrica grassland, 26 December 2006, ex residue in vial; 40 females, $A$. mangium plantation, 26 December 2006, ex residue in vial; 4 females, natural forest, 26 December 2006, ex O. schwaneri, O. rudis Sharp, 1875, and residue in vial; 3 females, burned ridges, 6-11 December 2008, ex residue in vials; 2 females, A. mangium plantations, 7-12 December 2008, ex residue in vials; 8 females, I. cylindrica grassland, 7-12 December 2008, ex residue in vial. Km 29: 165 females, 22 December 2006, ex O. schwaneri, O. cervicapra, O. obscurior, C. renaudpauliani, and residue in vials.

Diagnosis. Female. Dorsal setae j1 plumose distally; S5 and Z5 pilose in distal half; J5 entirely pilose; other setae simple (in some cases j4 pilose distally). Ornamentation of sternal shield distinct; l. ang., 1. m. t., and 1. o. p. distinct; 1. o. p. disjunct from l. m. t. and not bifurcate.

Habitat. This species has been collected from the scarab beetle genera Catharsius, Microcopris, Onthophagus, and Paragymnopleurus.

Distribution. Indonesia (Java, Kalimantan, Sumatra, Lombok, and Sumbawa).

\section{Macrocheles kalimantanensis Hartini and Takaku, 2003}

Macrocheles kalimantanensis Hartini and Takaku, 2003 in Hartini et al. 2003: 310-312, figs 1-2.

Material examined. SWPF: 25 females, 16 December 2006, ex Sisyphus thoracicus Sharp, 1875, Onthophagus pasificus, O. borneensis, and residue in vials; 19 females, 17 December 2006, ex O. semicupreus, O. schwaneri, O. borneensis, Onthophagus sp., and residue in vials; 7 females, 18 December 2006, ex S. thoracicus, O. waterstradti, and $O$. pastillatus; 27 females, 20 December 2006, ex O. obscurior, O. cervicapra, Paragymnopleurus maurus, Catharsius dayacus, and residue in vials; 38 females, 14 December 2007, ex O. waterstradti, O. incisus, O. schwaneri, O. cervicapra, O. vulpes, O. semicupreus, $C$. dayacus, $P$. maurus, and residue in vials; 16 females, 15 December 2007, ex C. dayacus, $P$. maurus, and O. schwaneri; 5 females, 15-20 December 2007, ex Copris sp.; 4 females, 20-25 December 2007, ex residue in vials; 48 females, 11 December 2008, ex O. borneensis and residue in vials; 20 females, 12 December 2008, ex $O$. obscurior, O. borneensis, O. pastillatus, $S$. thoracicus, $P$. maurus, O. semicupreus, and O. bonorae Zunino, 1976; 6 females, 5 December 2008, ex residue in vials; 1 female, 7 December 2008, ex residue in vials; 10 females, 10 December 2008, ex residue in vials. Km 12: 8 females, secondary forest, 15-20 December 2007, ex O. schwaneri. Km 23: 1 female, Imperata cylindrica grassland, 17-22 December 2007, ex residue in vial; 1 female, Acacia mangium plantation, 17-22 December 2007, ex residue in vial. $\mathbf{K m ~ 2 4 : ~} 1$ female, $A$. mangium plantation, 21 December 2006, ex Caccobius unicornis (Fabricius, 1798) ; 21 females, burned secondary forest, 21 December 2006, ex O. dux, P. maurus, and residue in vial; 16 females, secondary forest, 21 December 2006, ex O. schwaneri, O. aurifex, $O$. vulpes, $C$. dayacus, and residue in vial; 12 females, natural forest, 21 December 2006, ex O. schwaneri, C. dayacus, and residue in vial; 10 females, burned secondary forest, 26 December 2006, ex residue in vials; 6 females, $I$. cylindrica grassland, 26 December 2006, ex residue in vials; 32 females, A. mangium plantation, 26 December 2006, ex $O$. limbatus and residue in vials; 14 females, natural forest, 26 December 2006, ex O. cervicapra, O. schwaneri, O. rudis, and residue in vials; 18 females, burned ridge, 14-19 December 2007, ex C. dayacus, P. maurus, O. schwaneri, and residue in vials; 5 females, burned ridges, 19-24 December 2007 , ex residue in vials; 16 females, burned ridges, 6-11 December 2008, ex residue in vials; 20 females, A. mangium plantation, 7-12 December 2008, ex C. renaudpauliani and residue in vials; 3 females, I. cylindrica grassland, 7-12 December 2008, ex residue in vials. $\mathbf{K m}$ 29: 51 females, 22 
December 2006, ex O. schwaneri, O. cervicapra, C. renaudpauliani, and residue in vials. Km 38: 3 females, 16-21 December 2007, ex residue in vials.

Additional specimens examined, deposited in MZB: Sumatra: 1 female, $350 \mathrm{~m}$ alt., Mt. Leuser, Ketambe National Park, Nanggroe Aceh Darussalam, 4 September 1989, Habley and D. C. Darling leg., ex Onthophagus diabolicus Harold, 1877; 9 females, Biology Research Forest, Andalas University, Padang, West Sumatra, 3-7 November 2001, S. Hartini and G. Takaku leg., ex Catharsius sp. and Onthophagus sp. Bali: 1 female, Pancasari, Sukasada, Buleleng, 3 December 1999, S. Hartini and G. Takaku leg., ex Catharsius sp. Sulawesi: 1 female, Tountimomoro, North Sulawesi, 27 November 1999, S. Hartini and G. Takaku leg., ex Copris sp.

Diagnosis. Female. Dorsal shield oval, attenuate posteriorly; j1 plumose in distal half; z1 simple; 55 and z5 slightly pilose or simple; j6 simple; z6 and J2 simple but in some cases slightly pilose; other dorsal setae pilose; l. ang., l. arc., l. m. t., and l. o. p. with punctations along lines.

Habitat. This species has been collected from the scarab beetle genera Catharsius, Copris, Microcopris, Onthophagus, Paragymnopleurus, and Sisyphus.

Distribution. Indonesia [Kalimantan; Sumatra, Bali, and Sulawesi (new records)].

\section{Macrocheles kraepelini (Berlese, 1905)}

Holostaspis kraepelini Berlese, 1905: 164, fig. 26.

Macrocheles (Cophrolaspis) kraepelini: Berlese 1918: 146; Vitzthum 1926: 34-35.

Macrocheles (Cophrolaspis) multihamatus Vitzthum, 1926: 29-34, figs 20-22.

Macrocheles kraepelini: Krantz and Filipponi 1964: 40-42, figs 3-5, tav. II figs 1, 2; Halliday 1986: 743, figs 2, 33-39; Wallace 1986: 8-9, fig. 2F, pl. 1(3); Walter and Krantz 1986a: 212-213, figs 1-3; Walter and Krantz 1986b: 289; Halliday 2000: 298-299; Takaku 2001: 500-501, figs 2, 8; Hartini and Takaku 2003a: 1264.

Material examined. SWPF: 1 female, 15-20 December 2007, ex Copris sp.; 1 female, 7 December 2008, ex residue in vial; 1 female, 13 December 2008, ex residue in vial. Km 18: 1 female, Acacia mangium plantation, 23 December 2006, ex residue in vial. Km 22: 1 female, A. mangium plantation, 23 December 2006, ex residue in vial. $\mathbf{K m ~ 2 4 : ~} 2$ females, A. mangium plantation, 26 December 2006, ex residue in vial; 4 females, burned ridge, 14-19 December 2007, ex Onthophagus dux, O. schwaneri, and residue in vials; 1 female, burned valley, 5-10 December 2008, ex residue in vial; 1 female, Imperata cylindrica grassland, 7-12 December 2008, ex residue in vial. Km 29: 1 female, 22 December 2006, ex residue in vial. $\mathrm{Km}$ 38: 6 females, secondary forest, 16-21 December 2007, ex residue in vials.

Diagnosis. Female. Dorsal shield broadly rounded posteriorly; most of dorsal setae enlarged and pilose, except for simple setae j6, z5, z6, and J2; seta z1 occasionally pilose. Sternal shield with distinct ornamentation; 1 . ang. with many punctations; posterior 1. arc. concave; l. o. p. bifurcate; a.p.p. with strong punctations. Genu IV with 6 pectinate setae.

Habitat. This species has been collected from the scarab beetle genera Catharsius, Microcopris, Onthophagus, and Paragymnopleurus.

Distribution. Indonesia (Java, Kalimantan, and Sumatra), Malaysia, Philippines, Singapore, Thailand, Vietnam, India, Pakistan, Australia, Caroline Islands, Fiji, and Samoa.

\section{Macrocheles mammifer Berlese, 1918}

Macrocheles mammifer Berlese, 1918: 146, 162, 171.

Holostaspis polyornata Turk, 1948: 105.

Macrocheles pavlovskii Bregetova and Koroleva, 1960: 83; Karg 1971: 140.

Macrocheles postneri Krauss, 1970: 28.

Macrocheles tridentatus: Delfinado and Baker 1975: 53, not Pearse and Wharton 1936 in Pearse et al. 1936: 473 (misidentification).

Macrocheles mammifer: Bregetova 1977: 363; Wallace 1986: 11; Krantz and Whitaker 1988: 236.

Material examined. $\mathbf{K m}$ 22: 1 female, Imperata cylindrica grassland, 23 December 2006, ex residue in vial.

Diagnosis. Dorsal shield widely rounded, reticulate and micropunctured; lateral and marginal dorsal setae plumose distally except for s2, s6, and r4; 8 pairs of dorsocentral and mediolateral dorsal setae ( $\mathrm{j} 2, \mathrm{j} 5, \mathrm{j} 6, \mathrm{~J} 2, \mathrm{~J} 5, \mathrm{z} 1, \mathrm{z} 5$, and z6) smooth and needle-like; j1 brush-like, z2 pilose distally; ventral shield sculptured; sternal shield sparsely and irregularly punctured; sculptural lines absent; surface of epigyneal and ventrianal shield reticulate; ventrianal shield wider than long, with micropunctation in lateral areas.

Habitat. This species has been collected from scarab beetles and decaying substrates.

Distribution. Indonesia (Kalimantan; new record), Malaysia, Singapore, Philippines, Israel, Australia, Micronesia, Spain, Germany, Poland, Slovakia, Russia, USA, Trinidad, Cuba, and Argentina.

\section{Macrocheles merdarius (Berlese, 1889)}

Holostaspis merdarius Berlese, 1889, fasc. 52(1), fig. 103.

Macrocheles merdarius: Filipponi and Pegazzano, 1963: 8388, figs V, VI, tav. XXIV; Takaku and Hartini 2001: 326327; Hartini and Takaku 2003a: 1265; Hartini et al. 2003: 309; Hartini et al. 2005: 204; Hartini and Takaku 2006: 32.

Material examined. Km 22: 4 females, Imperata cylindrica grassland, 23 December 2006, ex residue in vial; $\mathbf{K m}$ 24: 1 female, Acacia mangium plantation, 26 December 2006, ex residue in vial.

Diagnosis. Female. All dorsal setae simple. L. o. a. of sternal shield connected by transverse lines; punctations very faint. Genu IV with 6 setae.

Habitat. This species has been collected from the scarab 
beetle genera Aphodius, Catharsius, Copris, Coptodactyla, Euoniticellus, Lepanus, Liatongus, Notopedana, Onthophagus, Pentodon, Coptodactyhanaeus, and Synapsidis, the geotropid beetle genus Geotrupes, the histerid beetle genus Pachylister, and from beetles of other families including Lucanidae, Silphidae, and Trogidae. It has also been recorded from rodents, soil, leaf litter, cow dung, compost, manure, etc.

Distribution. Cosmopolitan. In Indonesia, this species is known from Java, Kalimantan, Sulawesi, Bali, Lombok, Flores, Sumbawa, Sumba, and West Papua.

Macrocheles muscaedomesticae (Scopoli, 1772)

Acarus muscaedomesticae Scopoli, 1772: 125, 157.

Macrocheles muscaedomesticae: Pereira and de Castro 1945: 16-178, figs 1-22.

Material examined. SWPF. 1 female, 16 December 2006, ex Catharsius dayacus; 1 female, 20 December 2006, ex residue in vial; 1 female, 14 December 2007, ex Onthophagus schwaneri. Km 24: 1 female, burned secondary forest, 21 December 2006, ex O. waterstradti. Km 29: 1 female, 22 December 2006, ex residue in vial.

Diagnosis. Dorsal shield ornamented with reticulate pattern; $\mathrm{j} 1$ plumose in distal third; $\mathrm{j} 5, \mathrm{j} 6, \mathrm{~J} 2, \mathrm{z1}, \mathrm{z5}$, and z6 simple; other dorsal setae pilose in their distal third; sternal shield with punctures and ridges.

Habitat. This species has been collected from various kinds of animals, e.g., beetles, flies, moths, rodents, birds, etc., and various habitats, e.g., litter, rotting seaweed, bumble bee nests, compost, poultry manure, etc.

Distribution. Cosmopolitan. In Indonesia, this species is known from Java and Kalimantan (new record).

Macrocheles persimilis Hartini, Dwibadra and Takaku, 2007

Macrocheles persimilis Hartini, Dwibadra and Takaku, 2007: 82-83, 85, fig. 3.

Material examined. Km 22: 1 female, 23 December 2006, ex residue in vial. Km 24: 1 female, 26 December 2006, ex residue in vial.

Diagnosis. Dorsal shield oval, attenuate posteriorly; surface ornamented with distinct reticulations and punctations; lateral margin smooth; dorsal shield with 28 pairs of setae; j1-4 pilose distally; j5, j6, z1, z5, z6, and J2 simple; other dorsal setae pilose; sternal shield with one or two 1 . arc.

Habitat. This species has been collected from the scarab beetle genus Onthophagus.

Distribution. Indonesia [Sulawesi and Kalimantan (new record)].

Macrocheles sumbaensis Hartini and Takaku, 2005

Macrocheles sumbaensis Hartini and Takaku, 2005 in Hartini et al. 2005: 206-207, figs 6-11.
Material examined. $\quad \mathrm{Km}$ 23: 1 female, Acacia mangium plantation, 23 December 2006, ex residue in vial.

Diagnosis. Dorsal shield oval, surface ornamented with distinct reticulation and punctations; 28 dorsal setae; setae j1, Z4, Z5, and S5 pilose distally; J5 entirely pilose; other setae simple. Sternal shield with granular ornamentation, short lines and punctation in edges of shields; epygynial shield ornamented with punctate reticulation.

Habitat. This species has been collected from scarab beetles of the genus Aphodius and from the histerid beetle Pachylister lutarius (Erichson, 1834).

Distribution. Indonesia [Sumba and Kalimantan (new record)].

\section{Macrocheles dayaci Dwibadra and Takaku sp. nov.} (Fig. 1)

Type series. Holotype (MZB. Acar. 7559.2): female, Hutan Lindung Sungai Wain, Balikpapan, East Kalimantan, 20 December 2006, ex Catharsius dayacus, A. Ueda and D. Dwibadra leg. Paratypes: 1 female, data same as in holotype; Km 24: 2 females, 26 December 2006, ex residue in vial.

Description. Female. Length of dorsal shield 1035 (1020-1050), width at level of coxae II 627.5 (600-660) $(n=4)$. Specimens reddish brown in color.

Dorsum (Fig. 1A). Dorsal shield broadly rounded posteriorly with procurved outline, surface of shield covered with strong punctations and reticulation; lateral margin of shield smooth; shield bearing 28 pairs of dorsal setae and 22 pairs of pores; seta $\mathrm{j} 1$ pilose distally; $\mathrm{z} 1$ simple; other setae pilose distally.

Venter (Fig. 1B). Sternal shield wider than long; length 178.8 (175-180), width at level of coxae II 207.5 (200-210) $(n=4)$; shield with 3 pairs of simple setae and 2 pairs of pores; 1 . ang. and 1 . m. t. present; 1.o.a. with faint punctation; two punctate 1. arc. distinct; 1. o. p. present as distinct line, with punctations, connected to l. m. t.; a. p. p. with strong and coarse punctations. Metasternal shields oval and free; each shield with 1 simple seta and anterior pore.

Width of epigynial shield $273.8(270-275)(n=4)$; shield ornamented with punctations, with pair of simple setae on the posterior corner.

Ventrianal shield longer than wide, length 411.3 (400420 ), width 317.5 (295-340) $(n=4)$; shield with strong, dimpled reticulation and punctations; 3 pairs of preanal setae, 1 pair of paranal setae, and 1 postanal seta present; postanal seta pilose, other setae simple; cribrum located posterior to postanal seta.

Gnathosoma (Fig. 1C). Well developed and sclerotized. Deutosternal groove with 6 rows of denticles, anteriormost row divided; 3 pairs of simple hypostomal setae and 1 pair of simple palpcoxal setae present. Epistome (Fig. 1E) with median process and pair of lateral elements; median process bifurcate distally, and lacking minute spicules; basal margin serrate. Fixed digit of chelicera (Fig. 1D) with simple dorsal seta, robust median tooth, small distal tooth, pilus dentilis, and terminal hook; movable digit with robust bidentate median tooth, small distal tooth, and terminal hook; length of 


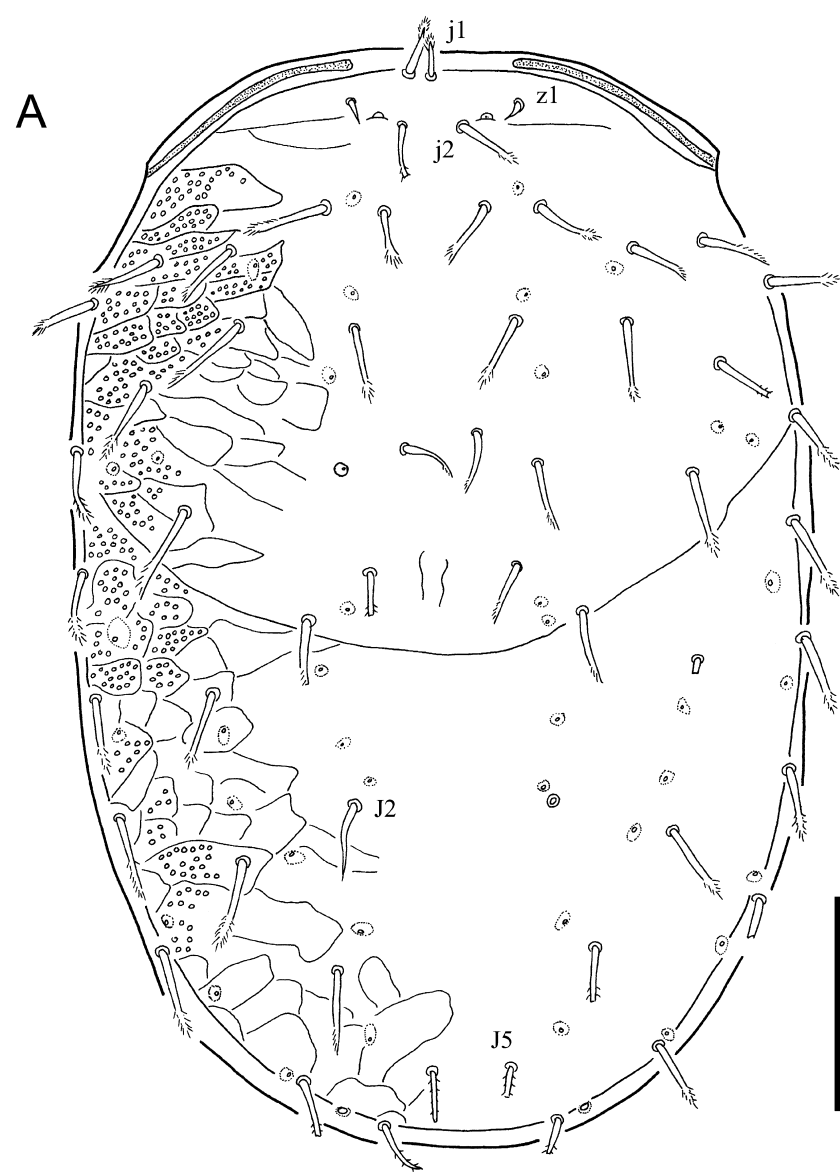

B
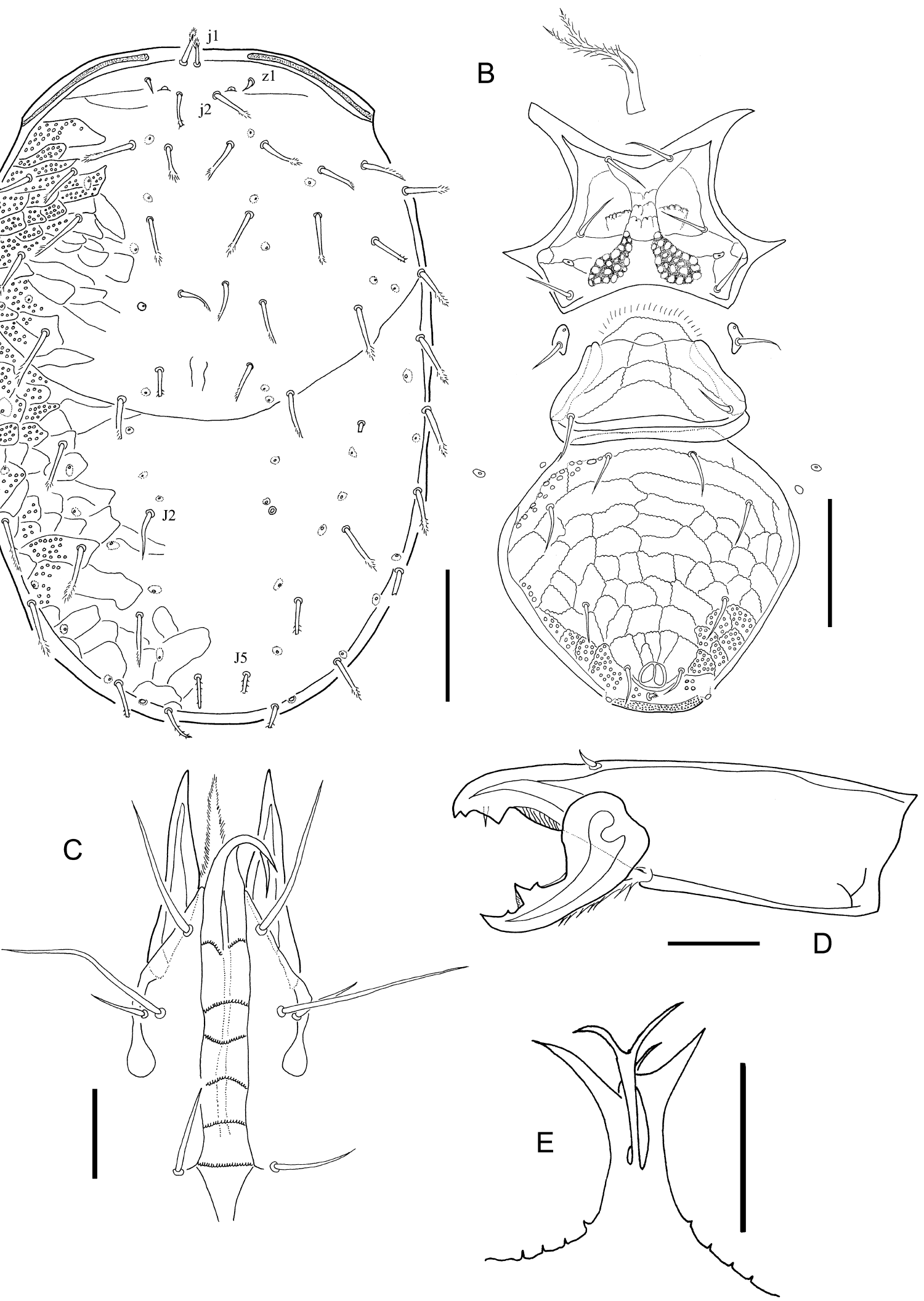

Fig. 1. Macrocheles dayaci Dwibadra and Takaku, sp. nov., female, holotype (MZB. Acar. 7559.2). A, dorsal shield; B, ventral shield (paratype, MZB. Acar. 7560.2); C, ventral view of gnathosoma; D, chelicera; E, tectum (paratype, MZB. Acar. 7559.1). Scale bars: $200 \mu \mathrm{m}$ (A, B); $50 \mu \mathrm{m}(\mathrm{C}-\mathrm{E})$.

fixed digit 220 (200-230) and movable digit 96.9 (95-100) $(n=4)$.

Legs. Most leg segments with simple and pilose setae ex- cept for coxae I-IV; trochanter I-III and tarsus I with only simple setae. Leg chaetotaxy typical for this genus. Genu IV with 6 pilose setae. Leg length (excluding ambulacrum, 
$n=4) ;$ leg I, 758.8 (720-830); leg II, 715.6 (647.5-765); leg III, 702.5 (660-760); leg IV, 1007.5 (945-1045).

Sacculus foemineus. Not observed.

Male and other stages. Unknown.

Etymology. The specific name is derived from the specific epithet of the phoretic host, the scarab beetle Catharsius dayacus.

Remarks. M. dayaci is a member of the glaber species group and is similar to M. witcoskyanus Walter and Krantz, 1986 (Walter and Krantz 1986b) in the shape of dorsal setae and shield sternal ornamentation. However, M. dayaci is distinguishable from $M$. witcoskyanus by the following characters (corresponding conditions of $M$. witcoskyanus in parentheses): 1) j4 and j5 pilose distally (simple); 2) z5 and j6 in some cases slightly pilose (simple); and 3) ventrianal shield not expanded, longer than wide (expanded laterally, wider than long).

Macrocheles riparius Dwibadra and Takaku sp. nov. (Fig. 2)

Type series. Holotype (MZB. Acar. 7566): female, Hutan Lindung Sungai Wain, Balikpapan, East Kalimantan, 20 December 2006, ex residue in vial, A. Ueda and D. Dwibadra leg. Paratypes: SWPF: 5 females, 17 December 2006, ex Onthophagus semicupreus, O. waterstradti, and residue in vials; 2 females, 20 December 2006, ex residue in vial; 1 female, 12 December 2008, ex residue in vial, other data same as holotype. Km 24: 2 females, Balikpapan, East Kalimantan, 21 December 2006, ex O. schwaneri, residue in vial.

Description. Female. Length of dorsal shield 731.5 (680-770), width at level of coxae II 467.5 (410-510) $(n=10)$. Specimens yellowish brown in color.

Dorsum (Fig. 2A). Dorsal shield with distinct punctations and reticulation; lateral margin of shield smooth; shield bearing 28 pairs of dorsal setae and 22 pairs of pores; seta $\mathrm{j} 1$ and Z5 pilose distally; J5 entirely pilose, $\mathrm{r} 2$ simple but sometimes slightly pilose; other setae simple.

Venter (Fig. 2B). Sternal shield wider than long; length 144 (130-150), width at level of coxae II 154.5 (150-160) $(n=10)$; shield with 3 pairs of simple setae and 2 pairs of pores; 1. ang. with punctation, disjunct from 1. arc.; 1. o. a. punctate; two l. arc. present as irregular punctate lines; $1 . \mathrm{m}$. t. punctate; 1. o. p. present as paired transverse lines, with punctations, not connected to $1 . \mathrm{m}$. t.; two a. p. l. present. Metasternal shields oval and free; each shield with 1 simple seta and an anterior pore.

Width of epigynial shield $184.5(160-200)(n=10)$; shield ornamented with punctuations and pair of simple setae.

Ventrianal shield longer than wide; length 260 (235-280), width $221(195-245)(n=10)$; shield ornamented with reticulation and punctations; 3 pairs of preanal setae, 1 pair of paranal setae, and 1 postanal seta present; postanal seta pilose, other setae simple; cribrum located posterior to postanal seta.

Gnathosoma (Fig. 2C). Well developed and sclerotized, differing from that of Macrocheles dayaci only in median process of epistome (Fig. 2E) bearing many small spicules.
Chelicera (Fig. 2D) same as in M. dayaci; length of fixed digit 217.5 (210-220) and movable digit 69.8 (67.5-72.5) $(n=10)$.

Legs. Most leg segments with simple and pilose setae except for coxae I-IV, trochanters I-III and tarsus I with only simple setae. Leg chaetotaxy typical for this genus. Genu IV with 6 pilose setae. Leg length (excluding ambulacrum, $n=10)$; leg I, 638.5 (610-665); leg II, 615 (585-680); leg III, 573.5 (525-625); leg IV, 847.5 (815-930).

Sacculus foemineus (Fig. 2F). Pair of sacculi present; cornu distinct, small and rounded distally; spermatheca oval.

Male and other stages. Unknown.

Etymology. This specific name alludes to its occurrence around the Wain River.

Remarks. The sternal punctate ornamentation of the present species is similar in pattern to that of Macrocheles adenostictus Krantz and Whitaker, 1988 (Krantz and Whitaker 1988) recorded from the USA. However, M. riparius is distinguishable by the following characters (corresponding conditions of $M$. adenostictus in parentheses): 1) most dorsal setae, including setae of $\mathrm{z}-\mathrm{Z}$ and $\mathrm{s}-\mathrm{S}$ series, simple (all $\mathrm{z}-\mathrm{Z}$ and s-S series setae strongly pilose distally); and 2) ophisthogastric setae simple (weakly pilose distally).

Macrocheles wainensis Dwibadra and Takaku sp. nov. (Fig. 3)

Type series. Holotype (MZB. Acar. 7562): female, Hutan Lindung Sungai Wain, Balikpapan, East Kalimantan, 20 December 2006, ex O. semicupreus, A. Ueda and D. Dwibadra leg. Paratypes: SWPF: 1 female, 16 December 2006, ex residue in vial; 1 female, 17 December 2006, ex O. semicupreus; 1 female, 18 December 2006, ex O. semicupreus; 2 females, 20 December 2006, ex O. semicupreus and Phaeocroops sp.; Km 24: 1 female, 21 December 2006, ex O. dux; 2 females, 26 December 2006, ex O. rudis and residue in vial; 1 female, 5-10 December 2008, ex residue in vial.

Description. Female. Length of dorsal shield 674 (640$740)$, width at level of coxae II $417.5(400-460)(n=10)$. Specimens yellowish brown in color.

Dorsum (Fig. 3A). Dorsal shield oval, attenuate posteriorly, strongly punctate laterally; punctation and reticulation indistinct in center of anterior half; lateral margin of shield smooth; shield bearing 28 pairs of dorsal setae and 22 pairs of pores; seta $j 1$ pilose distally; $\mathrm{z} 1$ simple and reaching to insertion of $\mathrm{j} 2 ; \mathrm{j} 5, \mathrm{j} 6, \mathrm{z} 5, \mathrm{z6}$, and $\mathrm{J} 2$ simple; other setae pilose entirely or in distal 2/3; some podonotal setae (e.g., z4-6) inserted on tubercles.

Venter (Fig. 3B). Sternal shield wider than long; length 139.5 (130-150), width at level of coxae II 154 (150-160) $(n=10)$; shield with 3 pairs of simple setae and 2 pairs of pores; 1 . ang present; 1 arc. and $1 . \mathrm{m}$. t. present as punctate transverse line; paired a. p. l. present; 1. o. p. present as punctate line; a. p. p. producing scattered punctations and not reaching to $1 . \mathrm{m}$. t. Metasternal shields oval and free; each shield with 1 simple seta and anterior pore.

Width of epigynial shield $171.5(160-185)(n=10)$; shield 

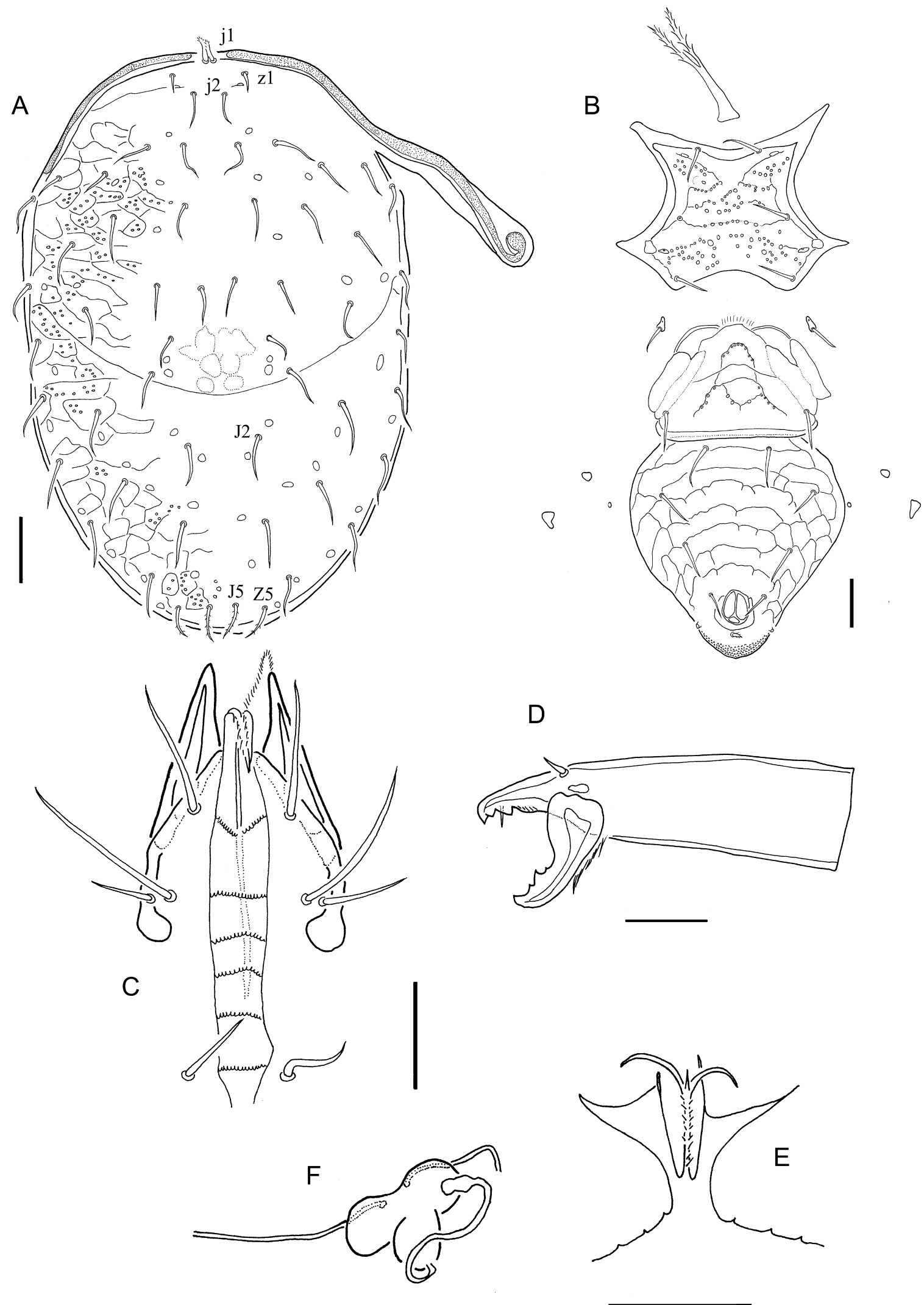

$\mathrm{D}$
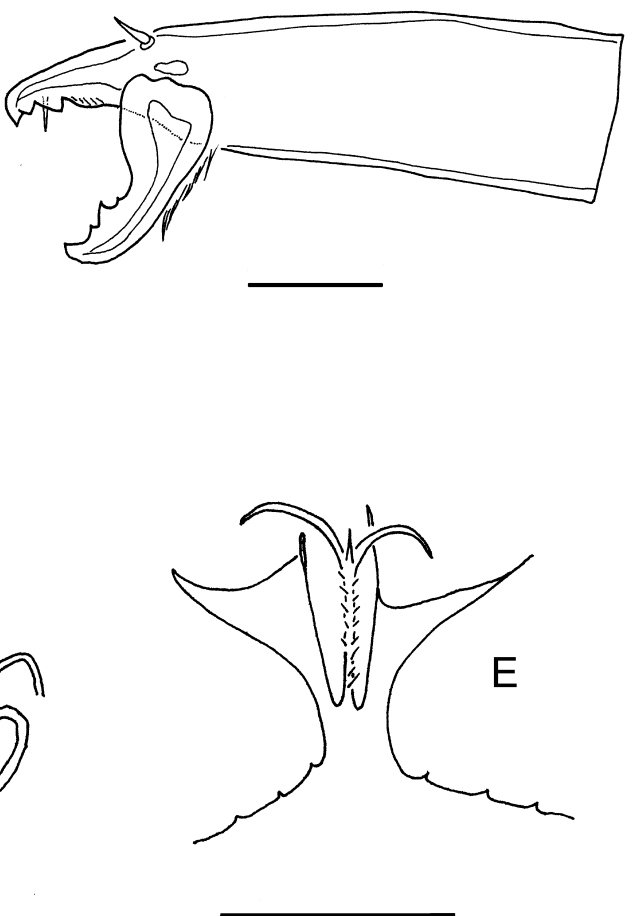

Fig. 2. Macrocheles riparius Dwibadra and Takaku, sp. nov., female, holotype (MZB. Acar. 7566). A, dorsal shield (paratype, MZB. Acar. 7565.2); B, ventral shield; C, ventral view of gnathosoma (paratype, MZB. Acar. 7565.2); D, chelicera; E, tectum; F, sacculus foeminus (paratype, MZB. Acar. 8205). Scale bars: $50 \mu \mathrm{m}$. 

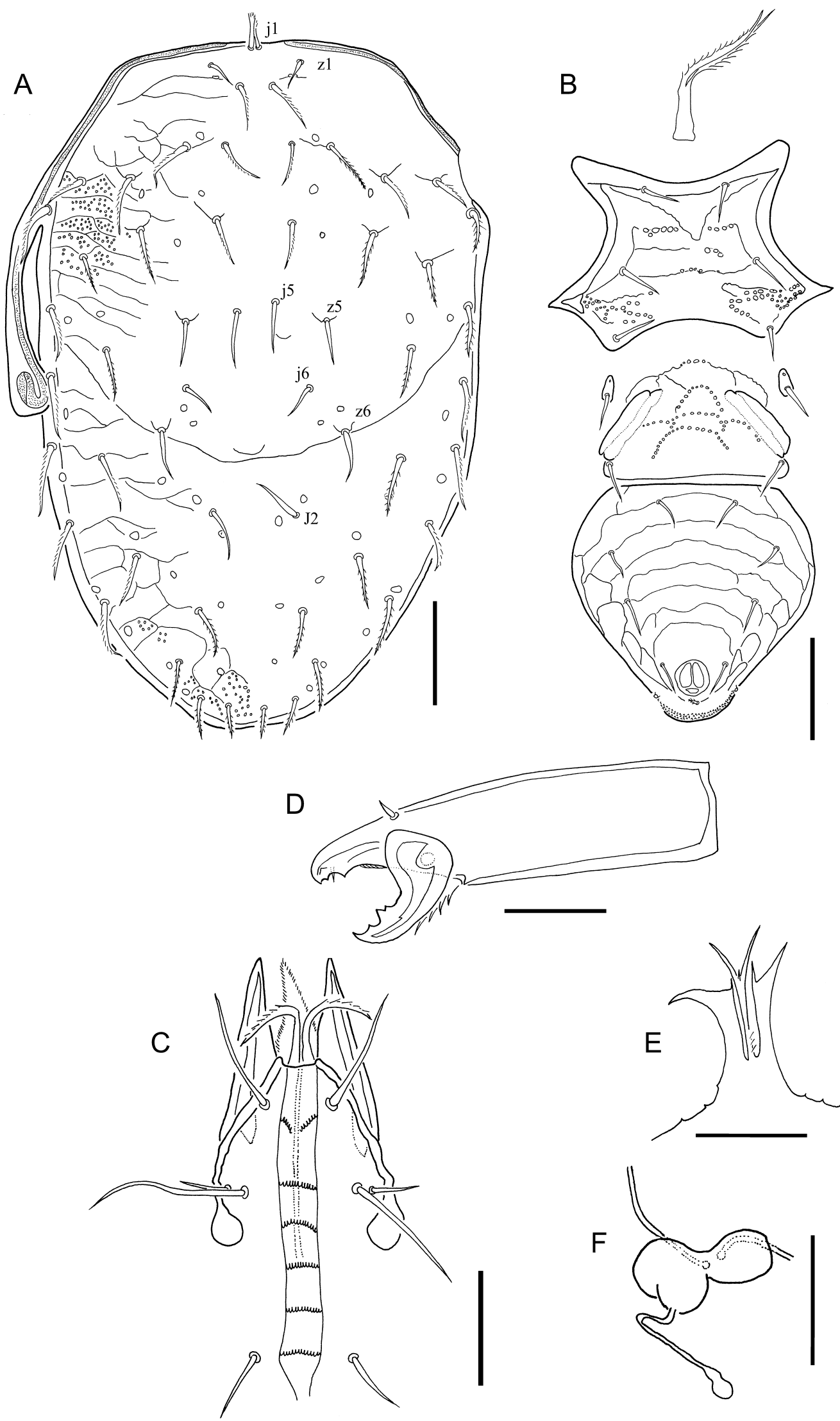

Fig. 3. Macrocheles wainensis Dwibadra and Takaku, sp. nov., female, holotype (MZB. Acar. 7562). A, dorsal shield; B, ventral shield; C, ventral view of gnathosoma (paratype, MZB. Acar. 7564); D, chelicera (paratype, MZB. Acar. 7563); E, tectum; F, sacculus foeminus (paratype, MZB. Acar. 8217). Scale bars: $100 \mu \mathrm{m}$ (A, B); $50 \mu \mathrm{m}$ (C-F). 
ornamented with punctuations and one pair of simple setae on the posterior corner.

Ventrianal shield longer than wide, length 234.5 (220$245)$, width $200.5(185-220)(n=10)$; shield ornamented with semiconcentric lines and reticulation; 3 pairs of preanal setae, 1 pair of paranal setae, and 1 postanal seta present; postanal seta pilose and other setae simple; cribrum located posterior to postanal seta.

Gnathosoma (Fig. 3C). Well developed and sclerotized. Features of gnathosoma, epistome (Fig. 3E), and chelicerae (Fig. 3D) similar to those of Macrocheles riparius. Length of fixed digit 198.5 (190-205) and that of movable digit 65.5 $(63.8-67.5)(n=10)$.

Legs. Most leg segments with simple and pilose setae except for coxae I, III, and IV; trochanter I and tarsus I with only simple setae. Leg chaetotaxy typical for this genus. Genu IV with 6 pilose setae. Leg length (excluding ambulacrum, $n=10)$; leg I, 521.5 (490-550); leg II, 518 (490-560); leg III, 476.8 (450-500); leg IV, 691.5 (620-770).

Sacculus foemineus (Fig. 3F). Very similar to that of Macrocheles riparius.

Male and other stages. Unknown.

Etymology. This specific name is derived from the type locality.

Remarks. M. wainensis is a member of the glaber species group. The pattern of sternal ornamentation in $M$. wainensis is similar to that of M. nataliae Bregetova and Koroleva, 1960 from Slovakia, as illustrated by Mašán (2003). Most of the dorsal setae are more or less pilose in M. wainensis whereas setae $\mathrm{j} 1, \mathrm{r} 2-\mathrm{r} 4, \mathrm{~J} 5, \mathrm{Z} 4, \mathrm{Z} 5$, and S5 are pilose and the other setae are simple in $M$. nataliae. There is some variation in the distribution of pilose setae in $M$. nataliae, as was noted in the drawing and description by Bregetova and Koroleva (1960), and as has been discussed by Hyatt and Emberson (1988). Also the pilose setae of specimens from Kalimantan are stronger in pilosity and mostly inserted in the tubercles. The dorsal setae in the present species are similar in shape to those of M. sukabumiensis Hartini and Takaku, 2003 (Hartini and Takaku 2003a), but the shapes of j5, j6, z5, z6, and J2 differ. Those setae are simple in M. wainensis, but pilose in M. sukabumiensis.

Genus Neopodocinum Oudemans, 1902 Neopodocinum bosschai (Oudemans, 1901)

Emeus bosschai Oudemans, 1901: 290-291, pl. VIII, figs 1618.

Cosmiphis bosschai: Vitzthum 1925: 33-36; 1926: 88-92, figs 55-57; Krantz 1965: 206; Hartini and Takaku 2004: 7789 , figs $1-21$.

Material examined. SWPF: 4 males, 7 deutonymphs, 5 protonymphs, 16 December 2006, ex Catharsius dayacus, residue in vials; 1 female, 2 males, 2 deutonymphs, 3 protonymphs, 20 December 2006, ex Paragymnopleurus maurus and residue in vials; 6 males, 3 deutonymphs, 6 protonymphs, 14 December 2007, ex C. dayacus, Onthophagus schwaneri, O. waterstradti and residue in vial; 1 male, 1 deutonymph, 15 December 2007, ex C. dayacus; 2 males, 15-20 December 2007, ex residue in vial; 1 male, 4 deutonymphs, 20-25 December 2007, ex residue in vial. Km 15: 1 protonymph, 19 December 2007, ex Scarabaeinae. Km 18: 1 deutonymph, Acacia mangium plantation, 23 December 2006, ex residue in vial. Km 22: 12 females, 2 deutonymphs, 1 protonymph, A. mangium plantation, 23 December 2006, ex O. schwaneri, C. renaudpauliani, and residue in vials. Km 23: 1 female, 1 male, 23 December 2006, ex C. renaudpauliani; 5 females, 4 males, 3 deutonymphs, 1 protonymph, 17-22 December 2007, ex residue in vial; 4 females, 2 males, 4 deutonymphs, $A$. mangium plantation, 17-22 December 2007, ex C. renaudpauliani, O. obscurior, and residue in vial. $\mathbf{K m ~ 2 4 : ~} 1$ male, A. mangium plantation, 21 December 2006, ex residue in vial; 3 females, 1 protonymph, 21 December 2006, ex C. renaudpauliani; 1 female, 1 deutonymph, burned secondary forest, 21 December 2006, ex C. dayacus; 1 female, 2 males, 1 deutonymph, 2 protonymphs, secondary forest, 21 December 2006, ex C. dayacus, S. thoracicus, and residue in vials; 1 male, 1 deutonymph, natural forest, 21 December 2006, ex residue in vial; 2 females, 1 male, Imperata cylindrica grassland, 26 December 2006, ex C. renaudpauliani and residue in vial; 12 females, 6 males, 9 deutonymphs, 7 protonymphs, A. mangium plantation, 26 December 2006, ex C. renaudpauliani, O. schwaneri, O. limbatus, and residue in vial; 2 females, 1 male, 3 deutonymphs, 4 protonymphs, natural forest, 26 December 2006, ex C. dayacus, O. vulpes, and residue in vials; 2 females, 1 male, 1 deutonymph, 1 protonymph, burned ridge, 14-19 December 2007, ex C. dayacus, O. schwaneri, O. $d u x$, and P. maurus; 1 male, 1 deutonymph, 1 protonymph, burned ridge, 19-20 December 2007, ex residue in vial; 2 deutonymphs, 6-11 December 2008, ex residue in vial; 1 female, 2 males, 3 deutonymphs, 1 protonymph, 7-12 December 2008, ex C. renaudpauliani and residue in vials; 1 female, 1 male, I. cylindrica grassland, 7-12 December 2008, ex residue in vial. Km 29: 19 females, 7 males, 4 deutonymphs, 5 protonymphs, 22 December 2006, ex O. schwaneri, O. cervicapra, C. renaudpauliani, and residue in vials.

Diagnosis. Dorsal shield of female oval, attenuate posteriorly; insertions of most pairs of dorsal setae connected by transverse ridges; shield with more than 40 pairs of dorsal setae, podonatal setae pilose in their distal half or $2 / 3$; opisthonotal setae broadened and pectinate; $1 . \mathrm{m}$. t. in sternal shield complete.

Habitat. This species has previously been collected from Heliocopris sp., Onthophagus schwaneri, Catharsius molossus (Linnaeus, 1758), Paragymnopleurus maurus, and decaying leaves.

Distribution. Indonesia (Sumatra and Kalimantan).

Neopodocinum kalimantanense Hartini and Takaku, 2004

Neopodocinum kalimantanense Hartini and Takaku, 2004: 77-89, figs 22-26.

Material examined. SWPF: 5 females, 16 Decem- 
ber 2006, ex Catharsius dayacus and residue in vials; 9 females, 20 December 2006, ex C. dayacus, Paragymnopleurus maurus, and residue in vials; 7 females, 14 December 2007, ex C. dayacus, O. schwaneri, and residue in vial; 1 female, 10 December 2008, ex residue in vial; 1 female, 15 December 2007, ex C. dayacus; 4 females, 20-25 December 2007, ex residue in vial. $\mathbf{K m ~ 2 4 : ~} 7$ females, secondary forest, 21 December 2006, ex C. dayacus, Sisyphus thoracicus, and residue in vials; 1 female, natural forest, 26 December 2006, ex residue in vial; 1 female, burned ridge, 14-19 December 2007, ex O. schwaneri; 1 female, Acacia mangium plantation, 7-12 December 2008, ex residue in vial.

Diagnosis. Females. Dorsal shield oval, bearing more than 50 pairs of dorsal setae and 22 pores; insertions of most dorsal setae away from midline and connected by short transverse ridges; lateral margin smooth; most podonotal setae pilose; medial setae from J5 to posteromarginal setae simple and short; lateral and marginal setae pectinate. Sternal shield with complete l. m. t.; all sternal setae simple and long, surpassing insertions of setae behind them.

Habitat. This species has previously been collected from Catharsius molossus.

Distribution. Indonesia (Kalimantan).

\section{Neopodocinum maius Berlese, 1911}

Neopodocinum maius Berlese, 1911: 431.

Neopodocinum cophrophilum Vitzthum, 1925: 20-21; 1926: 40-52, figs 25-34.

Neopodocinum maius: Krantz 1965: 185-187, figs 47-48; Hartini and Takaku 2004: 78.

Material examined. SWPF: 3 females, 4 males, 4 protonymphs, 16 December 2006, ex Catharsius dayacus and residue in vials; 3 females, 4 males, 1 protonymph, 20 December 2006, ex Onthophagus borneensis, Paragymnopleurus maurus and residue in vials; 1 female, 2 protonymphs, 20 December 2006, ex 4 females, 3 males, 1 deutonymph, 1 protonymph, 14 December 2007, ex O. schwaneri and C. dayacus; 1 deutonymph, 3 protonymphs, 15 December 2007, ex C. dayacus; 1 male, 1 deutonymph, 15-20 December 2007, ex residue in vial; 5 females, 20-25 December 2007, ex residue in vial. $\mathbf{K m}$ 24: 1 female, burned secondary forest, 21 December 2006, ex C. dayacus; 2 females, 1 protonymph, natural forest, 21 December 2006, ex residue in vials; 1 female, 1 deutonymph, natural forest, 26 December 2006, ex C. dayacus and residue in vials; 1 protonymph, burned ridge, 14-19 December 2007, ex $P$. maurus; 1 deutonymph, burned ridge, 19-24 December 2007, ex residue in vial; 2 females, 1 protonymph, burned ridge, 6-11 December 2008, ex residue in vial. Km 29: 1 protonymph, 22 December 2006, ex C. renaudpauliani.

Diagnosis. Female. Dorsal shield oval, bearing 28 pairs of setae; $\mathrm{j} 1$ and $\mathrm{z} 1$ plumose distally; unpaired seta Jx absent. Sternal shield broader than long; 1. m. t. complete; anal shield expanded laterally, subtriangular, without preanal setae; ophisthogastric setae pectinate or smooth.

Habitat. This species has previously been collected from Heliocopris sp., Catharsius molossus, and Onthophagus sp.

Distribution. Indonesia (Sumatra and Kalimantan).

Neopodocinum subjaspersi Hartini and Takaku, 2003

Neopodocinum subjaspersi Hartini and Takaku, 2003b: 5664, figs 26-29, 32-52, 56.

Neopodocinum subjaspersi: Hartini and Takaku 2004: 86.

Material examined. SWPF: 4 females, 1 male, 1 deutonymph, 6 protonymphs, 16 December 2006, ex Onthophagus sp., and residue in vials; 1 male, 1 protonymph, 20 December 2006, ex Onthophagus sp. and residue in vial; 7 females, 8 males, 10 deutonymphs, 19 protonymphs, 14 December 2007, ex O. schwaneri, O. borneensis, O. incisus, O. vulpes, O. semicupreus, Catharsius dayacus, and residue in vial; 2 females, 15 December 2007, ex $C$. dayacus and residue in vial; 1 female, 1 deutonymph, 1 protonymph, 15-20 December 2007, ex Copris sp. and residue in vial; 1 female, 20-25 December 2007, ex residue in vial. Km 24: 1 female, 1 deutonymph, natural forest, 21 December 2006, ex C. dayacus and residue in vial; 1 female, 1 male, burned ridge, 19-24 December 2007, ex residue in vial. Km 29: 1 female, 22 December 2006, ex O. schwaneri.

Diagnosis. Female. Dorsal shield oval, attenuate posteriorly; surface strongly punctate posteriorly; lateral margin smooth; shield bearing 28 pairs of setae and 22 pairs of

Table 1. Number of macrochelid mite species on Indonesian islands and other islands in the surrounding area, number of species common to Kalimantan and each island or country, and Sørensen's coefficient index. The number of species recorded from Kalimantan is 27, including the results of the present study. Data on species numbers are based on serial works by Hartini and Takaku, e.g., Hartini and Takaku (2003ac); Takaku et al. (2012), etc.

\begin{tabular}{|c|c|c|c|c|c|c|}
\hline & Philippines & Sumatra & Java & Sulawesi & $\begin{array}{l}\text { Lesser Sunda } \\
\text { Islands }\end{array}$ & $\begin{array}{l}\text { New Guinea } \\
\text { Island }\end{array}$ \\
\hline $\begin{array}{l}\text { Number of species recorded from Indonesian } \\
\text { islands and surrounding area }\end{array}$ & 21 & 21 & 36 & 20 & 19 & 17 \\
\hline $\begin{array}{l}\text { Number of species common to Kalimantan } \\
\text { and each island or country }\end{array}$ & 9 & 14 & 14 & 9 & 7 & 2 \\
\hline $\begin{array}{l}\text { Sørensen's coefficient index* between } \\
\text { Kalimantan and each island or country }\end{array}$ & 0.38 & 0.58 & 0.44 & 0.38 & 0.30 & 0.09 \\
\hline
\end{tabular}

*: Sørensen's coefficient index $=2 c /(a+b)$ (a: number of species recorded from area 1; b: number of species recorded from area 2; $c$ number of species common between area 1 and 2 ). 
pores; unpaired seta Jx present; setae $\mathrm{j} 1$ broad and plumose; setae z1 short and plumose; setae j2, s2, s6, r2, J2, S1-5 pilose, other setae simple.

Habitat. This species has previously been collected from Onthophagus sp. and C. molossus.

Distribution. Indonesia (Java, Sumatra, and Kaliman$\tan )$.

\section{Discussion}

As a result of our investigation of macrochelid mites in East Kalimantan, eight species were newly recorded from Kalimantan, three new species were added to the Kaliman$\tan$ macrochelid fauna, and the number of species of the family recorded as inhabiting the territory reached to 27 in total. Data on the number of species on some Indonesian islands and other islands in the area, the number of species common between islands, and Sørensen's similarity index are shown in Table 1. To date, the number of species in Kalimantan is similar to the number in the other Major Sunda Islands, i.e., Sumatra and Java. It has been well documented that species diversity of an island can be affected by island size (MacArthur and Wilson 1967). Larger islands generally support more species than smaller ones. Hartini (2005) reported that larger islands tend to harbour more macrochelid species than smaller one in Indonesia. Kalimantan is larger than other Major Sunda Islands, i.e: Java $\left(134,045 \mathrm{~km}^{2}\right)$, Sumatra $\left(524,100 \mathrm{~km}^{2}\right)$, and the Indonesian part of Borneo $\left(539,460 \mathrm{~km}^{2}\right)$ (MacKinnon et al., 1996), so the number of species in Kalimantan might be expected to exceed the number in Java and Sumatra. Of course, as Hartini (2005) mentioned, more humid and warmer islands tend to support more species than drier and cooler ones in Indonesia, since species number may be affected by precipitation, humidity, geological history, diversity of carrier species, and other biological or meteorological factors. In future studies we need to compare such data and analyze which factors affect diversity of these mites on the basis of plenty of faunal data.

Sørensen's coefficient index (Sørensen 1948), indicating similarity of fauna between two areas, is high between Kalimantan and Sumatra and between Kalimantan and Java. As well, several species in Kalimantan are common to the fauna of other surrounding islands, e.g., Sulawesi and the Philippines. These similarities may be due to the geological history of these islands and/or the dispersal ability of the phoretic vehicles, dung beetles. However, there has been no comprehensive study on phoretic macrochelid mites in most parts of Kalimantan and surrounding areas, and we lack enough data to conclude anything definite from our results. We need to study the Indonesian and SE Asian fauna further, and accumulate more data on the macrochelid mite and dung beetle faunas.

\section{Acknowledgments}

We would like to express our sincere thanks to Drs $\mathrm{H}$. Makihara, K. Matsumoto, K. Maeto (FFPRI, Japan), and Dr.Woro A. Noerdjito, who gave me (DD) the opportunity to join the project. Cordial thanks are also due to Dr Sri Hartini and reviewers for all of their valuable suggestions and to Miss Fatimah for all her help during this research. This study was supported by a grant from the Ministry of the Environment of Japan (Environmental Research by National Research Institutes of Government Ministries and Agencies, 2004-2008) and was partly supported by a Grantin-Aid for Scientific Research (C) (No. 23570102) from the Japan Society for the Promotion of Science.

\section{References}

Balogh, J. 1958. Macrocheliden aus Bulgarien (Acari, Mesostigmata). Acta Entomologica Musei Nationalis Pragae 32: 247-256.

Berlese, A. 1889. Acari, Myriopoda et Scorpiones Hucusque in Italia Reperta, fasc. 52 N. 1, Tipografia del Seminario, Padova, 19 pp + 10 pls.

Berlese, A. 1903. Acari nuovi. Manipulus I. Redia 1: 235-252.

Berlese, A. 1905. Acari nuovi. Manipulus IV. Redia 2: 154-176.

Berlese, A. 1910. Lista di nuove specie e nuovi generi di Acari. Redia 6: 242-271.

Berlese, A. 1911. Acarorum species novae quindecim. Redia 7: 429-435. Berlese, A. 1918. Centuria quarta di Acari nuovi. Redia 13: 115-192.

Berlese, A. 1920. Centuria quinta di Acari nuovi. Redia 14: 143-195.

Bregetova, N. G. 1977. Family Macrochelidae Vitzthum, 1930. Pp. 346-411. In: Gilyarov, M. S. (Ed.) Opredelitel'Obitayushchikh v Pochve Kleshchei Mesostigmata [Key to the Soil-Inhabiting Mites, Mesostigmata]. Nauka, Leningrad. [In Russian]

Bregetova, N. G. and Koroleva, E. V. 1960. The macrochelids mites (Gamasoidea, Macrochelidae) in the USSR. Parazitologicheskii Sbornik 19: 32-154. [In Russian]

Delfinado, M. D. and Baker, E. W. 1975. Mites (Acarina) associated with Popilius disjunctus (Illiger) (Coleoptera: Passalidae) in eastern United States. Journal of the New York Entomological Society 83: 49-59.

Evans, G. O. and Browning, E. 1956. British mites of the subfamily Macrochelinae Trägårdh (Gamasina-Macrochelidae). Bulletin of the British Museum (Natural History), Zoology 4: 1-55.

Evans, G. O. and Hyatt, K. H. 1963. Mites of the genus Macrocheles Latr. (Mesostigmata) associated with coprid beetles in the collections of the British Museum (Natural History). Bulletin of the British Museum (Natural History), Zoology 9: 327-401.

Filipponi, A. and Ilardi, A. 1958. Sulla validità di tre specie del sottogenere berlesiano Macrocheles (Acarina, Mesostigmata). Rivista di Parassitologia 19: 117-129.

Filipponi, A. and Pegazzano, F. 1960. Acari del genere Glyptholaspis nom. nov. pro Macrocheles (Macrocheles) Berl. 1918 (Mesostigmata, Macrochelidae). Redia 45: 133-171.

Filipponi, A. and Pegazzano, F. 1962. Acari Macrochelidi della collezione Berlese (Acarina, Mesostigmata, Macrochelidae) I - Gruppo Glyptholaspis. Rivista di Parassitologia 23: 173-205.

Filipponi, A. and Pegazzano, F. 1963. Specie italiane del grupposubbadius (Acarina, Mesostigmata, Macrochelidae). Redia 48: 69-91.

Filipponi, A. and Pegazzano, F. 1967 Contributo alla conoscenza del ge- 
nere Holostaspella Berlese, 1903 (Acarina, Mesostigmata, Macrochelidae). Redia 50: 219-259.

Filipponi, A. and Seganti, L. 1957. Arrenotochia in Macrocheles subbadius (Acarina, Mesostigmata). Rivista di Parassitologia 18: 27-33.

Frederiksson, G. M. and De Kam, M. 1999. Strategic Plan for the Conservation of the Sungai Wain Protection Forest, East Kalimantan. International Ministry of Forestry and Estate Crops-Tropenbos Kalimantan Project, Balikpapan, 38 pp.

Foà, A. 1900. Esistono il polimorfismo e la partenogenesi nei Gamasidi? Bolletino della Società Entomologica Italiana 32: 121-149.

Halliday, R. B. 1986. Mites of the genus Glyptholaspis Filipponi and Pegazzano (Acarina: Macrochelidae) in Australia. Journal of the Australian Entomological Society 25: 71-74.

Halliday, R. B. 1987. Further observations on the dorsal idiosomal chaetotaxy in the Macrochelidae (Acarina). International Journal of Acarology 13: 51-53.

Halliday, R. B. 2000. The Australian species of Macrocheles (Acarina: Macrochelidae). Invertebrate Taxonomy 14: 273-326.

Hartini, S. 2005. Taxonomic and Biogeographic Study of the Family Macrochelidae (Acari: Gamasina) Associated with Dung Beetles (Insecta: Coleoptera: Scarabaeidae) in Indonesia. Doctoral dissertation, Hokkaido University, Sapporo, 129 pp.

Hartini, S. and Takaku, G. 2003a. Javanese species of the mite genus Macrocheles (Arachnida: Acari: Gamasina: Macrochelidae). Zoological Science 20: 1261-1272.

Hartini, S. and Takaku, G. 2003b. Mites of the macrochelid genus Neopodocinum (Arachnida: Acari: Gamasida: Macrochelidae) associated with dung beetles in West Java, Indonesia. Species Diversity 8: 47-65.

Hartini, S. and Takaku, G. 2003c. A new species of Holostaspella (Arachnida: Acari: Macrochelidae) from Kalimantan, Indonesia. Species Diversity 8: 347-351.

Hartini, S. and Takaku, G. 2004. Neopodocinum mites (Arachnida: Acari: Macrochelidae) in Kalimantan. Species Diversity 9: 77-89.

Hartini, S. and Takaku, G. 2006. Mites of the genus Macrocheles (Acari: Gamasida: Macrochelidae) associated with dung beetles in Papua, Indonesia. Journal of the Acarological Society of Japan 15: 29-46.

Hartini, S., Dwibadra, D. and Takaku, G. 2007. Macrochelid mites (Acari: Gamasina: Macrochelidae) associated with dung beetles in Sulawesi, Indonesia. Journal of the Acarological Society of Japan 16: 73-96.

Hartini, S., Dwibadra, D. and Takaku, G. 2009. Mites of family Macrochelidae (Acari: Gamasida) associated with dung beetles in $\mathrm{Mt}$ Merapi National Park, Jogyakarta, Java, Indonesia. Entomological Science 12: 416-426.

Hartini, S., Takaku, G. and Katakura, H. 2003. Macrochelid mites of the genus Macrocheles (Acari: Macrochelidae) in Kalimantan, Indonesia. International Journal of Acarology 29: 307-313.

Hartini, S., Takaku, G., Kojima, J. and Katakura, H. 2005. Macrochelid mite fauna in the eastern part of the Lesser Sunda Islands, with description of two new species. Entomological Science 8: 201-209.

Hyatt, K. H. and Emberson, R. M. 1988. A review of the Macrochelidae (Acari: Mesostigmata) of the British Isles. Bulletin of the British Museum (Natural History), Zoology 54: 63-125.

Karg, W. 1971. Acari (Acarina), Milben. Unterordnung Anactinochaeta (Parasitiformes). Die freilebenden Gamasina (Gamasides), Raubmilben. Die Tierwelt Deutschlands 59: 1-475.

Krantz, G. W. 1965. A review of the genus Neopodocinum Oudemans, 1902 (Acarina, Macrochelidae). Acarologia 7: 139-226

Krantz, G. W. 1967. Insects of Micronesia. Acarina: Mesostigmata: Macrochelidae. Insects of Micronesia 3: 149-154.

Krantz, G. W. 1972. Macrochelidae from Hamburg (Acari Mesostigmata), with descriptions of two new species. Entomologische Mit- teilungen aus dem Zoologischen Museum Hamburg 4: 263-275.

Krantz, G. W. and Filipponi, A. 1964. Acari della famiglia Macrochelidae (Mesostigmata) nella collezione del South Australian $\mathrm{Mu}-$ seum. Rivista di Parassitologia 25: 35-54.

Krantz, G. W. and Whitaker, J. O. 1988. Mites of the genus Macrocheles (Acari: Macrochelidae) associated with small mammals in North America. Acarologia 29: 225-259.

Krauss, W. 1970. Die europäischen Arten der Gattungen Macrocheles Latreille 1829 und Geholaspis Berlese, 1918. Acarologie. Schriftenreihe für Vergleichende Milbenkunde 14: 1-43.

Latreille, P. A. 1829. Les Arachnides (Arachnides). Pp. 206-291. In: Cuvier, G. (Ed.) Le Regne Animal. Second edition. Vol. 4. Déterville, Paris.

MacArthur, R. H. and Wilson, E. O. 1967. The Theory of Island Biogeography. Princeton University Press, Princeton, 203 pp.

MacKinnon, K., Hatta, G., Halim, H. and Mangalik, A. 1996. The Ecology of Kalimantan, Indonesian Borneo. The Ecology of Indonesia Series. Vol III. Periplus Editions, Hongkong, $802+$ xxiv pp.

Mašán, P. 2003. Macrochelid Mites of Slovakia (Acari, Mesostigmata, Macrochelidae). Institute of Zoology, Slovak Academy of Sciences, Bratislava, 149 pp.

Oudemans, A. C. 1901. Notes on Acari. Tijdschrift der Nederlandsche Dierkundige Vereeniging 7: 276-311.

Oudemans, A. C. 1902. New list of Dutch Acari. Second part. Tijdschrift voor Entomologie 45: 1-52.

Pearse, A. S., Patterson, M. T., Rankin, J. S., and Wharton, G. W. 1936. The ecology of Passalus cornutus Fabricius, a beetle which lives in rotting logs. Ecological Monograph 6: 455-490.

Pereira, C. and de Castro, M. P. 1945. Contribuicäo para o conhecimento da espécie tipo de "Macrocheles Latr." ("Acarina”): " $M$. muscaedomesticae (Scopoli, 1772)" ermend. Arquivos do Instituto Biologico 16: 152-186.

Roy, R. K. 1989a. Mites of the genus Holostaspella (Acari: Mesostigmata: Macrochelidae) in India. Pp. 329-342. In: Channabasavanna, G. P. and Viraktamath, C. A. (Eds) Progress in Acarology, Vol. 1. E. J. Brill, Leiden.

Roy, R. K. 1989b. Indian species of the genus Glyptholaspis (Acari: Macrochelidae) with description of two new species. Pp. 343-53. In: Channabasavanna, G. P. and Viraktamath, C. A. (Eds) Progress in Acarology, Vol. 1. E. J. Brill, Leiden.

Scopoli, J. A. 1772. Annus historieo naturalis. C. G. Hilsoheri, Lipsiae. [Not seen].

Sørensen, T. 1948. A method of establishing groups of equal amplitude in plant sociology based on similarity of species content and its application to analyses of the vegetation on Danish commons. Biologiske Skrifter 5: 1-34.

Takaku, G. 1998. Descriptions of immature stages and male of Macrocheles hallidayi Walter and Krantz, 1986 (Acari: Macrochelidae). Journal of the Acarological Society of Japan 7: 29-38.

Takaku, G. 2001. Macrochelid mites (Acari: Macrochelidae: Macrocheles, Holostaspella) associated with scarab beetles in Sumatra, Indonesia. Tropics 10: 497-507.

Takaku, G. and Hartini, S. 2001. Macrochelid mites (Arachnida: Acari: Macrochelidae: Glyptholaspis, Macrocheles, Neopodocinum) associated with dung beetles in Bali, Indonesia. Species Diversity 6: 323-345.

Takaku, G., Hartini, S., Dwibadra, D. and Corpuz-Raros, L. A. 2012. Macrochelid mites (Acari: Gamasina: Macrochelidae) in the Philippines. Journal of the Acarological Society of Japan 21: 95-124.

Turk, F. A. 1948. Insecticolous Acari from Trinidad, B. W. I. Proceedings of the Zoological Society of London 118: 82-125.

Vitzthum, H. G. 1925. Fauna Sumatrensis (Beitrag Nr. 5): Acarinae. Supplementa Entomologica 11: 1-78.

Vitzthum, H. G. 1926. Malayische Acari. Treubia 8: 1-198. 
Wallace, M. M. H. 1986. Some macrochelid mites (Acari: Macrochelidae) associated with Australian dung beetles (Coleoptera: Scarabae). Acarologia 26: 3-15.

Walter, D. E. and Krantz, G. W. 1986a. Description of the Macrocheles kraepelini species complex (Acari: Macrochelidae) with two new species. Canadian Journal of Zoology 64: 212-217.

Walter, D. E. and Krantz, G. W. 1986b. A review of glaber-group (s. str.) species of the genus Macrocheles (Acari: Macrochelidae), and a discussion of species complexes. Acarologia 27: 277-294.

Walter, D. E. and Krantz, G. W. 1992. A review of glaber-like species with reduced sclerotization and ventral ornamentation the scutatus subgroup (Acari: Macrochelidae: Macrocheles). International Journal of Acarology 18: 241-249. 